\title{
Spectrophotometric Analysis of Phosphoric Acid Leakage in High-Temperature Phosphoric Acid-Doped Polybenzimidazole Membrane Fuel Cell Application
}

\author{
Seungyoon Han, ${ }^{1}$ Yeon Hun Jeong, ${ }^{1,2}$ Ju Hae Jung, ${ }^{1}$ Alina Begley, ${ }^{1}$ \\ Euiji Choi, ${ }^{1}$ Sung Jong Yoo, ${ }^{1}$ Jong Hyun Jang, ${ }^{1,3}$ Hyoung-Juhn Kim, ${ }^{1}$ \\ Suk Woo Nam, ${ }^{1,3}$ and Jin Young Kim ${ }^{1}$ \\ ${ }^{1}$ Fuel Cell Research Center, Korea Institute of Science and Technology, Hwarangno 14-gil 5, Seongbuk-gu, \\ Seoul 136-791, Republic of Korea \\ ${ }^{2}$ Department of Chemical and Biological Engineering, Korea University, Seoul 136-701, Republic of Korea \\ ${ }^{3}$ Green School, Korea University, 145 Anam-ro, Seongbuk-gu, Seoul 136-701, Republic of Korea \\ Correspondence should be addressed to Jin Young Kim; jinykim@kist.re.kr
}

Received 10 September 2015; Revised 21 November 2015; Accepted 29 November 2015

Academic Editor: Fanli Meng

Copyright (C) 2016 Seungyoon Han et al. This is an open access article distributed under the Creative Commons Attribution License, which permits unrestricted use, distribution, and reproduction in any medium, provided the original work is properly cited.

\begin{abstract}
High-temperature proton exchange membrane fuel cells (HT-PEMFCs) utilize a phosphoric acid- (PA-) doped polybenzimidazole (PBI) membrane as a polymer electrolyte. The PA concentration in the membrane can affect fuel cell performance, as a significant amount of PA can leak from the membrane electrode assembly (MEA) by dissolution in discharged water, which is a byproduct of cell operation. Spectrophotometric analysis of PA leakage in PA-doped polybenzimidazole membrane fuel cells is described here. This spectrophotometric analysis is based on measurement of absorption of an ion pair formed by phosphomolybdic anions and the cationoid color reagent. Different color reagents were tested based on PA detection sensitivity, stability of the formed color, and accuracy with respect to the amount of PA measured. This method allows for nondestructive analysis and monitoring of PA leakage during HT-PEMFCs operation.
\end{abstract}

\section{Introduction}

Proton exchange membrane fuel cells (PEMFCs) have been of great interest to research, as these energy conversion devices pose a promising environmentally friendly alternative to fossil fuel-based technologies [1]. In particular, high-temperature (HT) PEMFCs operating at temperatures between $100^{\circ} \mathrm{C}$ and $200^{\circ} \mathrm{C}$ offer many benefits over lowtemperature PEMFCs operating systems below $100^{\circ} \mathrm{C}$, such as improved electrode reaction kinetics, superior water and heat management, tolerance of fuel impurities, and increased waste heat utilization [2-5].

In HT-PEMFCs the usual solvent, water, is replaced with the proton conductive phosphoric acid (PA) in order to operate at such high temperatures $\left(\sim 200^{\circ} \mathrm{C}\right)$ and provide improved chemical and physical characteristics $[6,7]$. PA is also an essential component for proton transport in the membrane structure. For HT-PEMFCs, the PA-doped polybenzimidazole (PBI) membrane [8] is the only membrane which satisfies the U.S. Department of Energy target of 2015, so that many studies attempt to improve and optimize the material selection as well as investigate the degradation mechanism of the membrane in HT-PEMFCs [9-12].

The membrane degradation mechanism has been studied in depth in the last few decades [13-20]; however, the distribution and quantitative analysis of PA has been more or less neglected. A study concerning the amount and distribution of PA in PA-doped PBI membrane electrode assembly [21] is critical for the deep understanding of the degradation mechanism on the HT-PEMFCs performance [13, 22-24].

In this study, a simple colorimetric analysis of PA leakage in the PA-PBI membrane fuel cell is reported for the first time. The applicability of the colorimetric analysis method on HT-PEMFCs for PA at constant current density operation is 
presented. The selected method is shown to be a reliable and sensitive method of detection of PA, with a linear dynamic range of up to $1 \times 10^{-5} \mathrm{M}$ and a detection limit of $1 \times 10^{-8} \mathrm{M}$.

\section{Materials and Methods}

2.1. Color Developing Solution. All chemicals used were analytical grade reagents, and deionized water was used to produce all solutions.

For the molybdenum blue reaction (Table 1 ), $0.6 \mathrm{~g}$ of ammonium molybdate tetrahydrate and $0.024 \mathrm{~g}$ of potassium antimony tartrate hydrate were dissolved in $30 \mathrm{~mL}$ deionized water. $10 \mathrm{~mL}$ of $7.4 \mathrm{M}$ concentrated sulfuric acid, $10 \mathrm{~mL}$ of $0.44 \mathrm{M}$ ammonium sulfamate, and $10 \mathrm{~mL}$ of $0.4 \mathrm{M} \mathrm{L}$-ascorbic acid were added to produce the color reagent solution. Then, $1 \mathrm{~mL}$ of the color reagent solution was added to $6 \mathrm{~mL}$ of the sample solution.

For the crystal violet reaction (Table 3), $1.2 \times 10^{-2} \mathrm{M}$ ammonium molybdate tetrahydrate, $6.5 \mathrm{~N}$ of $98 \%$ concentrated sulphuric acid, and $1 \times 10^{-3} \mathrm{M}$ of crystal violet solution were prepared. Then, $3 \mathrm{~mL}$ of prepared color reagent solution was added to $7 \mathrm{~mL}$ of the sample solution in a $1: 1: 1 \mathrm{v} / \mathrm{v} \mathrm{mix-}$ ture of ammonium molybdate tetrahydrate, $6.5 \mathrm{~N}$ sulphuric acid, and $1 \times 10^{-5} \mathrm{M}$ crystal violet solution.

For the rhodamine $\mathrm{B}$ reaction (Table 2), $7.4 \times 10^{-3} \mathrm{M}$ ammonium molybdate tetrahydrate, $1 \times 10^{-3} \mathrm{M}$ rhodamine $\mathrm{B}$, $0.6 \mathrm{~N}$ of $98 \%$ concentrated sulphuric acid, and $0.05 \mathrm{M} \mathrm{NaOCl}$ solution were prepared. Then, $4 \mathrm{~mL}$ of color reagent solution was mixed with $6 \mathrm{~mL}$ of the sample solution in a $1: 1: 1: 1$ $\mathrm{v} / \mathrm{v}$ mixture of molybdate, $0.6 \mathrm{~N}$ sulphuric acid, $\mathrm{NaOCl}$, and diluted rhodamine $\mathrm{B}$ solution $\left(1 \times 10^{-5} \mathrm{M}\right)$.

2.2. Measurement of Sample Solutions from the Operating Cell. Commercially available MEA $\left(20.25 \mathrm{~cm}^{2}\right.$ active area, Dongjin Semichem), Teflon gaskets, and graphite bipolar plates were assembled and used for HT-PEMFC operation. The unit cell was operated on constant current density at $1.1 \mathrm{~A} \mathrm{~cm}^{-2}$ for 84 hours, the cell operation temperature was $150^{\circ} \mathrm{C}$, and the stoichiometry of hydrogen and air was 1.2 and 2.0 , respectively. During the cell operation, the exhaust gases from both anode and cathode were cooled and collected in liquid state in the vials which contained $10 \mathrm{~mL}$ of distillated water. Then, the reagents were added to the vent solutions from the unit cell. After the color reaction, the solutions with added reagent were analyzed by UV/Vis spectroscopy. The spectrophotometer used was a LAMBDA $25 \mathrm{UV} / \mathrm{Vis}$ spectrophotometer from PerkinElmer.

\section{Results and Discussion}

The quantitative analysis of PA leakage during the PA-doped PBI membrane HT-PEMFCs operation was performed by spectrophotometric analysis of the colorimetric reaction of the PA-molybdenum compound $[25,26]$. As shown in Figure 1, during cell operation the water byproduct dragged the PA, which was then discharged from the MEA. In the molybdenum blue color developing reaction, PA ions reacted
TABLE 1: Color reagent, molybdenum blue.

\begin{tabular}{lc}
\hline Compound & Quantity \\
\hline Ammonium molybdate tetrahydrate & $0.6 \mathrm{~g}$ \\
Potassium antimony tartrate hydrate & $0.024 \mathrm{~g}$ \\
Deionized water & $30 \mathrm{~mL}$ \\
Sulfuric acid $(7.4 \mathrm{M})$ & $10 \mathrm{~mL}$ \\
Ammonium sulfamate $(0.44 \mathrm{M})$ & $10 \mathrm{~mL}$ \\
L-Ascorbic acid $(0.4 \mathrm{M})$ & $10 \mathrm{~mL}$ \\
\hline
\end{tabular}

TABLE 2: Color reagent, rhodamine B.

\begin{tabular}{lc}
\hline Compound & Volume ratio \\
\hline Ammonium molybdate tetrahydrate $\left(7.4 \times 10^{-3} \mathrm{M}\right)$ & 1 \\
Rhodamine $\mathrm{B}\left(1 \times 10^{-3} \mathrm{M}\right)$ & 1 \\
Sulphuric acid $(0.6 \mathrm{~N})$ & 1 \\
$\mathrm{NaOCl}$ solution $(0.05 \mathrm{M})$ & 1 \\
\hline
\end{tabular}

TABLE 3: Color reagent, crystal violet.

\begin{tabular}{lc}
\hline Compound & Volume ratio \\
\hline Ammonium molybdate tetrahydrate $\left(1.2 \times 10^{-2} \mathrm{M}\right)$ & 1 \\
Sulphuric acid $(6.5 \mathrm{~N})$ & 1 \\
Crystal violet solution $\left(1 \times 10^{-3} \mathrm{M}\right)$ & 1 \\
\hline
\end{tabular}

with ammonium molybdate and formed phosphomolybdenum complexes. The complexes were reduced by ascorbic acid and heteropoly molybdenum blue was formed. The chemical equation is as follows [27-29]:

$$
\begin{aligned}
& 12 \mathrm{MoO}_{3}+\mathrm{H}_{2} \mathrm{PO}_{4}{ }^{-} \longrightarrow\left[\mathrm{H}_{2} \mathrm{PMo}_{12} \mathrm{O}_{40}\right] \\
& {\left[\mathrm{H}_{2} \mathrm{PMo}_{12} \mathrm{O}_{40}\right]+\text { Ascorbic acid }} \\
& \longrightarrow \text { Heteropoly molybdenum blue }
\end{aligned}
$$

The quantitative analysis was carried out on the resulting colored sample.

3.1. Selection of Color Reagent Solution. One of the PA detection methods used in this study was based on the analysis of the absorption spectrum of heteropoly molybdenum blue, the product of PA ions reacting with molybdate, followed by reduction with stannous chloride. The chemical equation is shown below $[27,28,30]$ :

$$
\begin{aligned}
& 12 \mathrm{MoO}_{3}+\mathrm{H}_{2} \mathrm{PO}_{4}{ }^{-} \longrightarrow\left[\mathrm{H}_{2} \mathrm{PMo}_{12} \mathrm{O}_{40}\right] \\
& {\left[\mathrm{H}_{2} \mathrm{PMo}_{12} \mathrm{O}_{40}\right]+\mathrm{SnCl}_{2}} \\
& \longrightarrow \text { Heteropoly molybdenum blue }
\end{aligned}
$$

This compound showed poor detection limit ( $>10 \mathrm{ppb})$ and low sensitivity. As an improvement to the heteropoly molybdenum blue method, stannous chloride was replaced with ascorbic acid to provide a stable reduction reaction, as well as a clear spectrum of molybdenum blue [28].

The sensitivity of the color reagent is defined in terms of apparent molar absorptivity. Color reagents must have a high 


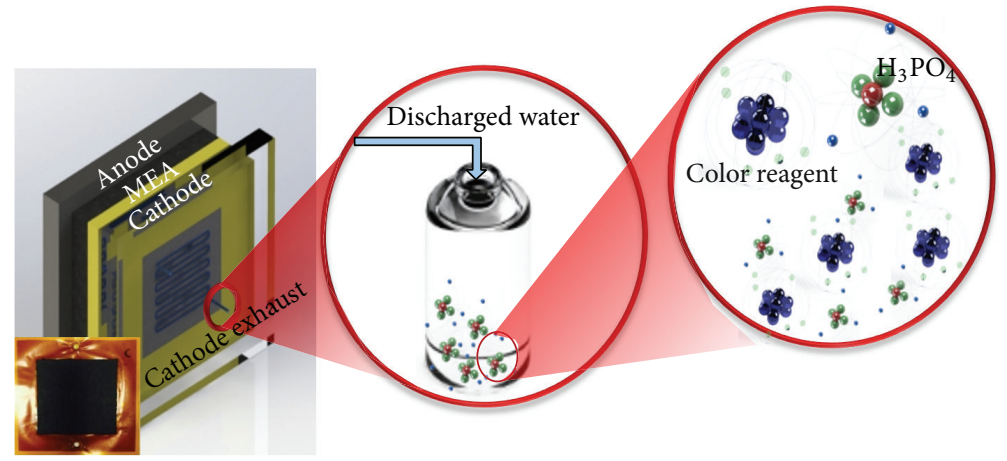

FIGURE 1: A schematic depiction of the approach of colorimetric detection of PA leakage in HT-PEMFCs used in the experiment.

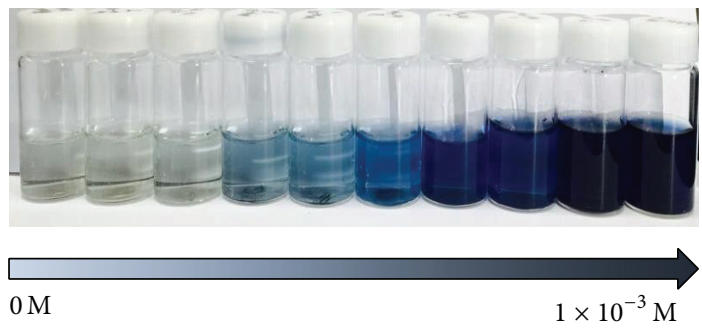

(a)

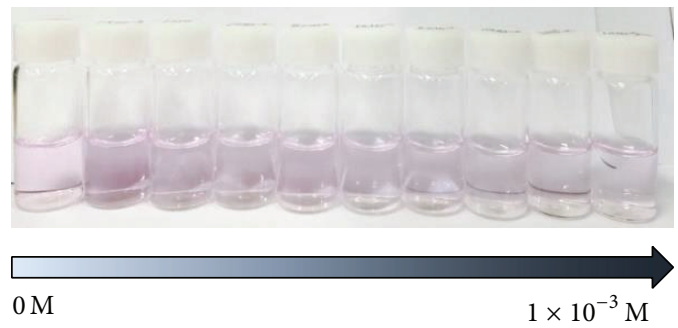

(b)

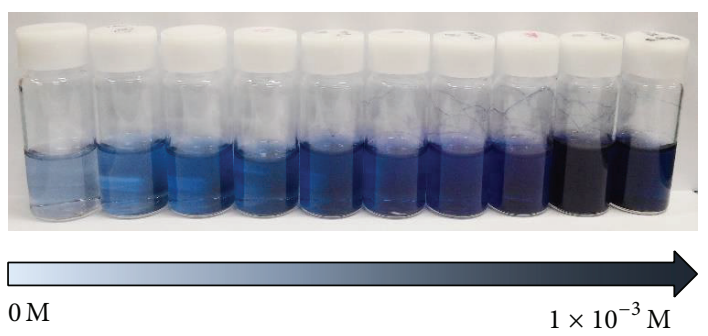

(c)

FiguRE 2: PA analysis from model PA compound solution. (a) Molybdenum blue method, (b) rhodamine B, and (c) crystal violet color reagent.

apparent molar absorptivity and be a cationoid dye, which allows the formation of an ion pair with molybdophosphoric acid. Table 4 [28] lists the apparent molar absorptivity of various commercially available color reagents.

Three major selection criteria are applied to the choice of color reagent for PA analysis: (1) the detection accuracy; (2) the color formation time and color stability; and (3) the detection limit at low PA concentration. There are many well-studied color reagents that can be applied to detecting low PA concentrations; however, the three chosen for this experiment were molybdenum blue [31], rhodamine B [32, 33], and crystal violet [34] methods. These color reagents have high apparent molar absorptivities, which result in higher detection sensitivity; they are also readily soluble in water and form cationic aqueous solutions.

3.2. Visual Inspection of Color Formation on PA Standard Solution. Each color reagent was tested with PA standard solution with a concentration range of $0 \mathrm{M}$ to $1 \times 10^{-3} \mathrm{M}$.
TABLE 4: Molar absorptivity of color reagents [28].

\begin{tabular}{lc}
\hline Color reagent & Molar absorptivity $\left(\mathrm{M}^{-1} \mathrm{~cm}^{-1}\right)$ \\
\hline Molybdenum blue & $2.0 \times 10^{4}$ \\
Brilliant green & $0.88 \times 10^{5}$ \\
Crystal violet & $1.28 \times 10^{5}$ \\
Malachite green & $7.8 \times 10^{4}$ \\
Rhodamine B & $1.19 \times 10^{5}$ \\
Servon red L & $0.7 \times 10^{4}$ \\
\hline
\end{tabular}

Gradation of each color dye is shown in Figure 2. Each color reagent solution had a similar color gradation pattern but different color spectral wavelength range in standard solution. As in Figures 2(a) and 2(c), both molybdenum blue and crystal violet resulted in blue color formation; however, the crystal violet resulted in a weaker color gradation than the molybdenum blue. This may imply that the visual detection 


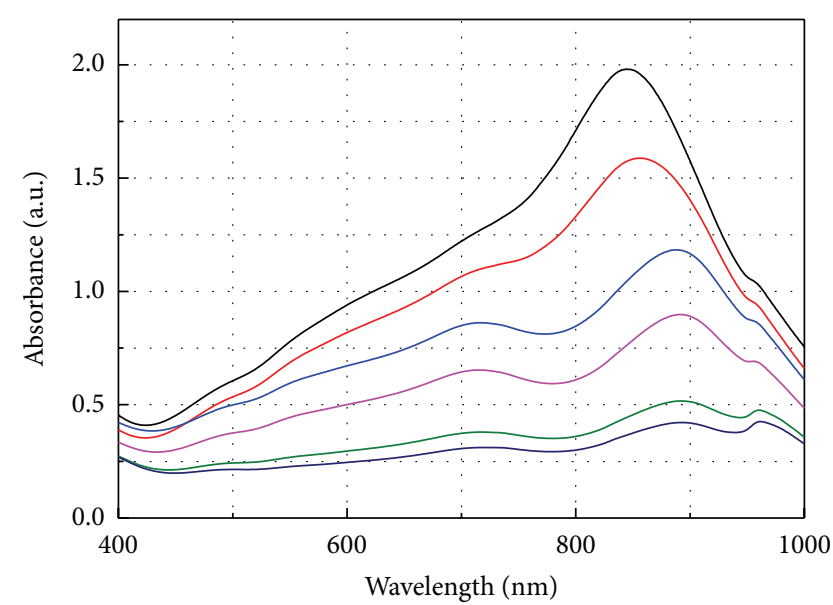

(a)

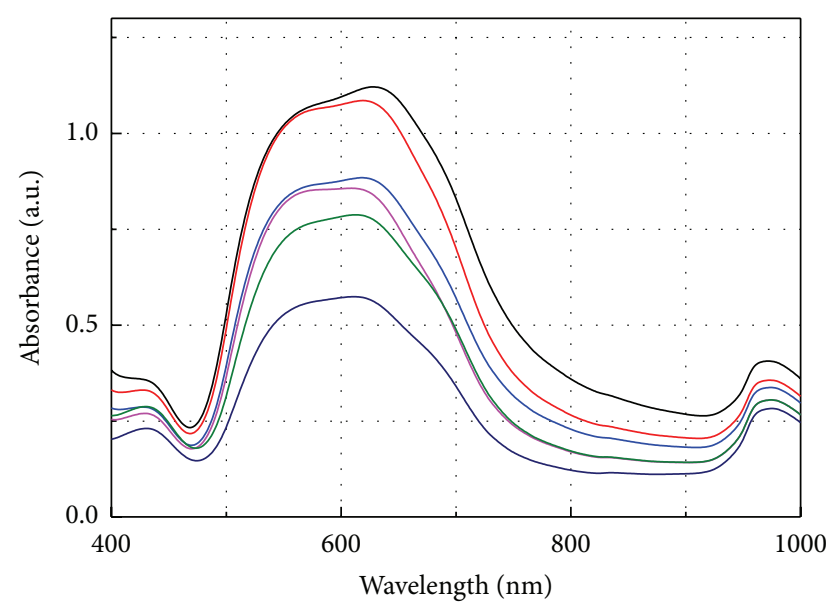

(b)

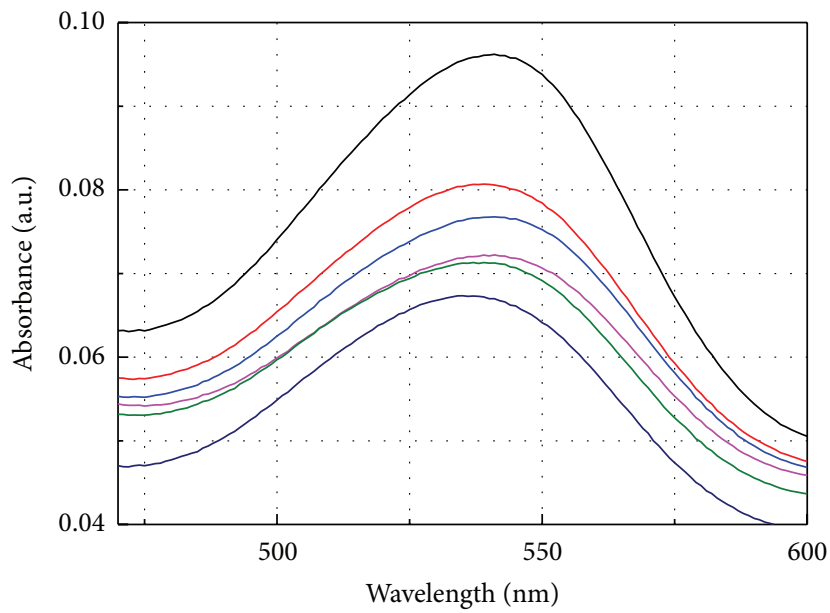

(c)

FIGURE 3: Spectrometric measurement of standard solution reacted with (a) molybdenum blue, (b) rhodamine B, and (c) crystal violet color reagent.

sensitivity of crystal violet is constant over a wide PA concentration range. Also, the color developing time of molybdenum blue and crystal violet was $15 \mathrm{~min}$ and $60 \mathrm{~min}$, respectively. The longer reaction time of crystal violet was mainly due to the strong color of the dye itself, so that unreacted crystal violet ions had to decolorize by reaction with acid before only the product could be detected. The chemical equation of the crystal violet method is as follows [27]:

$$
\begin{aligned}
& 12 \mathrm{MoO}_{3}+\mathrm{H}_{2} \mathrm{PO}_{4}^{-} \longrightarrow\left[\mathrm{H}_{2} \mathrm{PMo}_{12} \mathrm{O}_{40}\right] \\
& {[\mathrm{CV}]^{+}+\left[\mathrm{H}_{2} \mathrm{PMo}_{12} \mathrm{O}_{40}\right]^{-}} \\
& \longrightarrow[\mathrm{CV}]\left[\mathrm{H}_{2} \mathrm{PMo}_{12} \mathrm{O}_{40}\right]+[\mathrm{CV}]^{+} \\
& {[\mathrm{CV}]^{+}+[\mathrm{CV}]\left[\mathrm{H}_{2} \mathrm{PMo}_{12} \mathrm{O}_{40}\right]+\mathrm{H}^{+}} \\
& \longrightarrow[\mathrm{CV}]\left[\mathrm{H}_{2} \mathrm{PMo}_{12} \mathrm{O}_{40}\right]
\end{aligned}
$$

in which CV represents crystal violet compound.
The reaction with rhodamine $\mathrm{B}$ resulted in a distinct, light pink color. The chemical equation of the rhodamine $\mathrm{B}$ reaction is as follows [27]:

$$
\begin{aligned}
& 12 \mathrm{MoO}_{3}+\mathrm{H}_{2} \mathrm{PO}_{4}{ }^{-} \longrightarrow\left[\mathrm{H}_{2} \mathrm{PMo}_{12} \mathrm{O}_{40}\right] \\
& {[\mathrm{RhB}]^{+}+\left[\mathrm{H}_{2} \mathrm{PMo}_{12} \mathrm{O}_{40}\right]^{-}} \\
& \longrightarrow[\mathrm{RhB}]\left[\mathrm{H}_{2} \mathrm{PMo}_{12} \mathrm{O}_{40}\right]+[\mathrm{RhB}]^{+} \\
& {[\mathrm{RhB}]^{+}+[\mathrm{RhB}]\left[\mathrm{H}_{2} \mathrm{PMo}_{12} \mathrm{O}_{40}\right]+\mathrm{NaOCl}} \\
& \longrightarrow[\mathrm{RhB}]\left[\mathrm{H}_{2} \mathrm{PMo}_{12} \mathrm{O}_{40}\right]
\end{aligned}
$$

where $\mathrm{RhB}$ represents rhodamine $\mathrm{B}$ compound. In reaction (4), the concentration of rhodamine $\mathrm{B}$ and $\mathrm{NaOCl}$ had a critical impact on the color formation $[27,28]$. The $\mathrm{NaOCl}$ bleached rhodamine $\mathrm{B}$, but the optimized concentration of $\mathrm{NaOCl}$ required bleaching only the unreacted rhodamine $\mathrm{B}$ in the solution. 


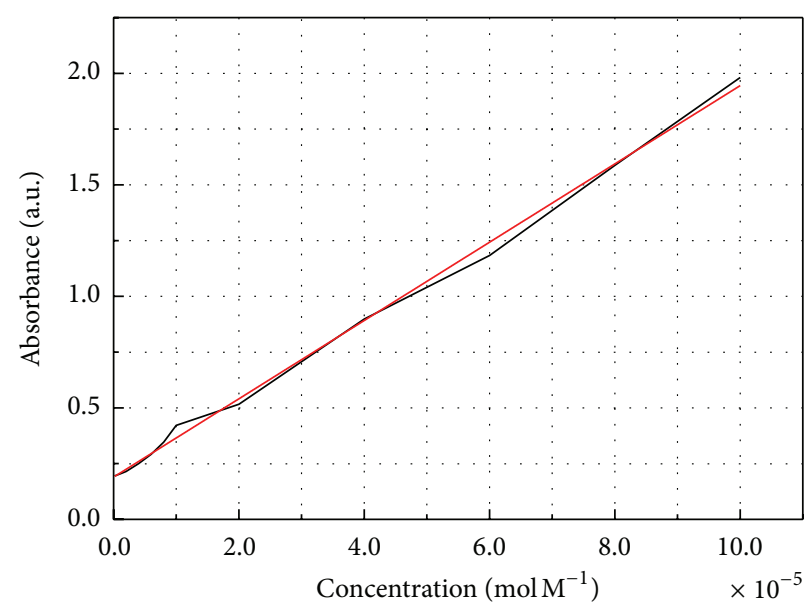

— Measured

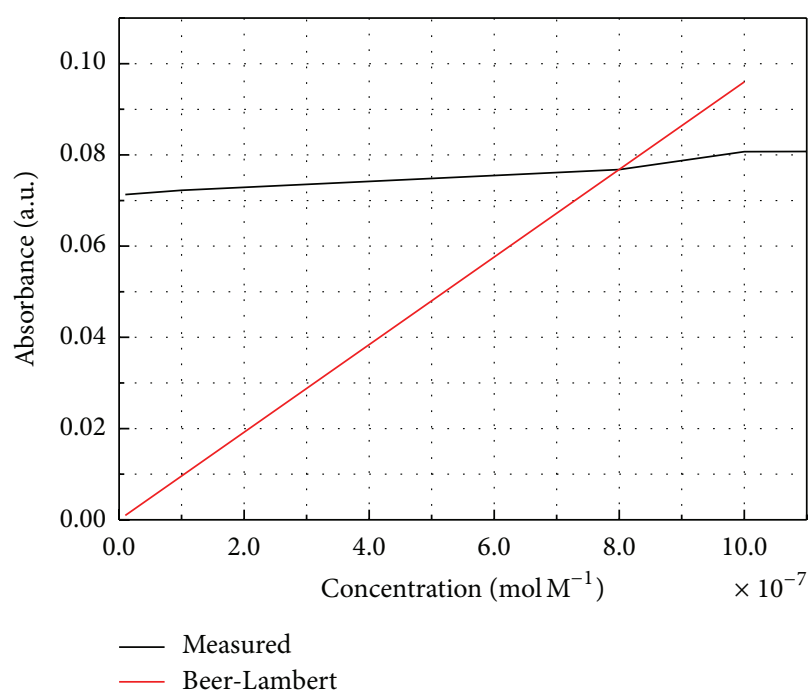

(b)

(a)

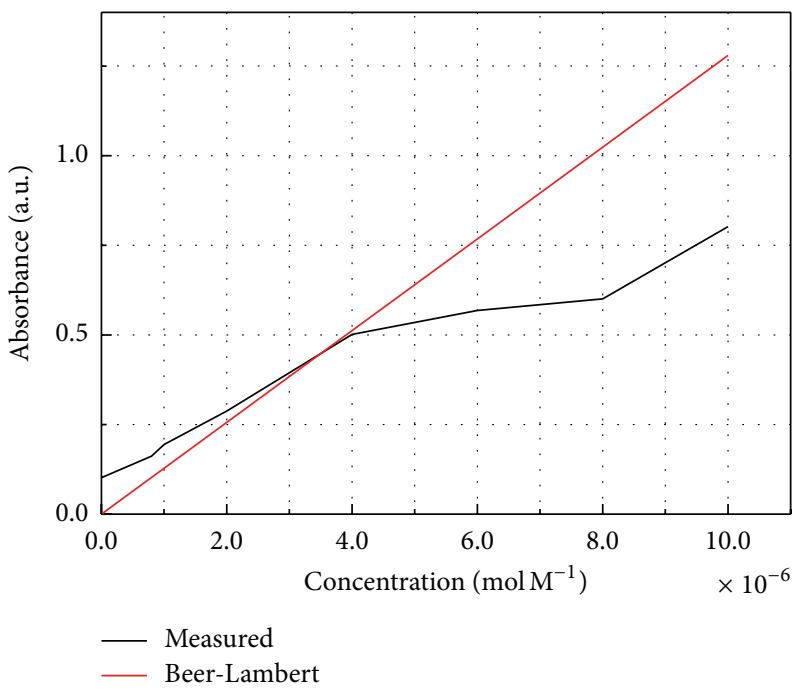

(c)

FIGURE 4: Relationship between PA concentration and the absorbance of standard solutions reacted with (a) molybdenum blue, (b) rhodamine $\mathrm{B}$, and (c) crystal violet color reagent.

\subsection{Spectrophotometric Measurement of PA Standard Solution.} The PA concentration was determined by the absorption spectra in standard solution, molybdenum blue, crystal violet, and rhodamine B solution. Clear absorption peaks were observed in each color reagent as shown in Figure 3. As mentioned above, since the heteropolyphosphoric acid, which is a colorific compound, was formed after the color developing reaction, the curves have more than one peak. In this case, the peak of maximum absorbance is chosen. The range of the absorption maxima of each reagent was as follows: $770 \mathrm{~nm}$ to $900 \mathrm{~nm}$ for molybdenum blue; $500 \mathrm{~nm}$ to $575 \mathrm{~nm}$ for crystal violet; and $550 \mathrm{~nm}$ to $700 \mathrm{~nm}$ for rhodamine B $[26,28]$. The maximum absorbance was plotted against PA concentration, yielding a linear correlation. The degree of linearity was analyzed by the Least Mean Square method [35] and the residual value $\left(R^{2}\right)$. The $R^{2}$-value was
0.99996 for molybdenum blue; 0.98768 for rhodamine B; and 0.99879 for the crystal violet solution. In addition to the residual value, a Lambert-Beer plot [36], obtained by standard solution PA concentration, and measured resulting absorbance are compared in Figure 4. The calibration curves in Figure 4 were plotted with apparent molar absorptivity data obtained from other investigators [28]. Linearity of the rhodamine B and crystal violet methods, Figures 4(b) and $4(\mathrm{c})$, respectively, was low. This revealed that the light pink rhodamine $\mathrm{B}$ has a low detection range and high potential error, crystal violet less so. Both color reagents required the decoloring of unreacted pigment through chemical reaction [28]. During the bleaching process, the $\mathrm{pH}$ of the decolorizing solution was a major factor that could destroy the desired, fully reacted product. Lastly, the detection limit for each color reagent was defined as a 1:1 signal to noise ratio, by which the 


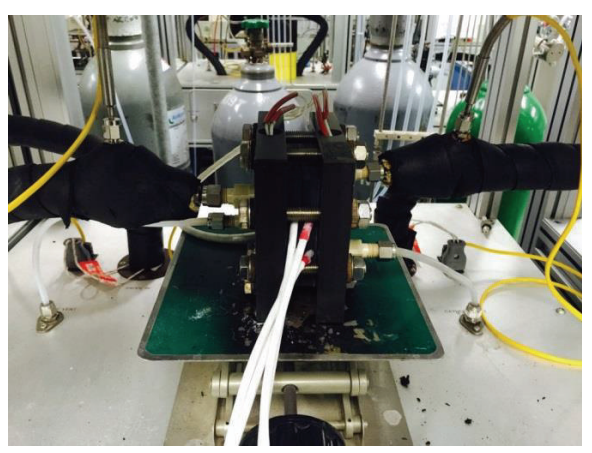

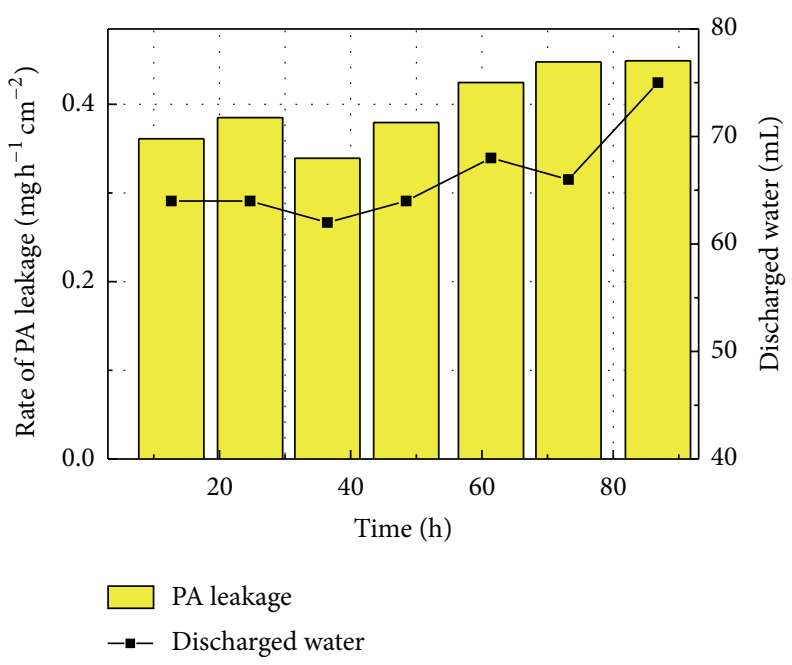

(b)

Figure 5: Applicability of the colorimetric method to real device. (a) Photograph of operating real device. (b) Histogram of PA contents and discharged water as a function of operation time.

noise was the maximum signal variance of the determined PA concentration. Upon analysis of all coloring reagents, molybdenum blue was best suited for the detection of PA concentration.

3.4. High-Temperature PEMFC Application. The molybdenum blue method was applied for quantitative analysis of leaked PA concentration from HT-PEMFCs (Figure 5). After 100 hours of constant current density fuel cell operation, the exhaust water was removed from the anode and cathode side outlets. During constant current cell operation with a fixed current density of $1.1 \mathrm{~A} \mathrm{~cm}^{-2}$, the rate of water discharge was also constant as the oxygen reduction reaction produced water in the fuel cell at a constant rate. It is known that the PA is in the liquid state inside the fuel cell and is presumably moved out of the membrane by water, as the dominant leakage source was discharged water [19]. Figure 5(b) indicates the amount of phosphoric acid from cathode of the unit cell during constant current operation at $1.1 \mathrm{~A} \mathrm{~cm}^{-2}$ for 84 hours. The average PA leakage of the seven samples was $0.397 \mu \mathrm{g} \mathrm{h}^{-1} \mathrm{~cm}^{-2}$, which is a negligible amount when compared to the initial PA concentration in the HT-PEMFCs MEA. The reliability of the molybdenum blue method was confirmed through inductively coupled plasma atomic emission spectroscopy (ICP-OES). The accuracy of PA concentration from the molybdenum blue method was over $99.21 \%$, which supported the computability and accuracy of the molybdenum blue method.

\section{Conclusions}

Recently, various investigation methods for PA concentration in the HT-PEMFCs have been studied and proposed; however, the spectrometric quantification with a color reagent solution is the most efficient method. Color reagents which have high apparent molecular absorptivity were selected and tested. The molybdenum blue and ascorbic acid method provided the most stable and reliable results, especially with respect to detecting speed and accuracy. The application of spectrometric quantification of PA leakage on the HTPEMFCs is a competitive method.

\section{Conflict of Interests}

The authors declare no competing financial interests.

\section{Acknowledgments}

This study was supported by the Korean Government through the New and Renewable Energy Core Technology Program of the Korea Institute of Energy Technology Evaluation and Planning (KETEP) funded by MOTIE (no. 2010T100200501). This work was also financially supported by KIST through institutional project (no. 2E25411).

\section{References}

[1] A. Chandan, M. Hattenberger, A. El-Kharouf et al., "High temperature (HT) polymer electrolyte membrane fuel cells (PEMFC) - a review," Journal of Power Sources, vol. 231, pp. 264-278, 2013.

[2] J. Lee, J. Jung, J. Y. Han et al., "Effect of membrane electrode assembly fabrication method on the single cell performances of polybenzimidazole-based high temperature polymer electrolyte membrane fuel cells," Macromolecular Research, vol. 22, no. 11, pp. 1214-1220, 2014.

[3] H. Su, C. Felix, O. Barron et al., "High-performance and durable membrane electrode assemblies for high-temperature polymer electrolyte membrane fuel cells," Electrocatalysis, vol. 5, no. 4, pp. 361-371, 2014.

[4] V. Mehta and J. S. Cooper, "Review and analysis of PEM fuel cell design and manufacturing," Journal of Power Sources, vol. 114 , no. 1, pp. 32-53, 2003. 
[5] R. K. A. M. Mallant, "PEMFC systems: the need for high temperature polymers as a consequence of PEMFC water and heat management," Journal of Power Sources, vol. 118, no. 1-2, pp. 424-429, 2003.

[6] J. Zhang, Z. Xie, J. Zhang et al., "High temperature PEM fuel cells," Journal of Power Sources, vol. 160, no. 2, pp. 872-891, 2006.

[7] S. H. Eberhardt, M. Toulec, F. Marone, M. Stampanoni, F. N. Buchi, and T. J. Schmidt, "Dynamic operation of HTPEFC: in-operando imaging of phosphoric acid profiles and (Re)distribution," Journal of the Electrochemical Society, vol. 162, no. 3, pp. F310-F316, 2015.

[8] Q. F. Li, H. C. Rudbeck, A. Chromik et al., "Properties, degradation and high temperature fuel cell test of different types of PBI and PBI blend membranes," Journal of Membrane Science, vol. 347, no. 1-2, pp. 260-270, 2010.

[9] Q. Li, J. O. Jensen, R. F. Savinell, and N. J. Bjerrum, "High temperature proton exchange membranes based on polybenzimidazoles for fuel cells," Progress in Polymer Science, vol. 34, no. 5, pp. 449-477, 2009.

[10] A. S. Aricò, A. Stassi, E. Modica et al., "Performance and degradation of high temperature polymer electrolyte fuel cell catalysts," Journal of Power Sources, vol. 178, no. 2, pp. 525-536, 2008.

[11] J. Wu, X. Z. Yuan, J. J. Martin et al., "A review of PEM fuel cell durability: degradation mechanisms and mitigation strategies," Journal of Power Sources, vol. 184, no. 1, pp. 104-119, 2008.

[12] J. Hu, H. Zhang, Y. Zhai, G. Liu, J. Hu, and B. Yi, "Performance degradation studies on $\mathrm{PBI} / \mathrm{H}_{3} \mathrm{PO}_{4}$ high temperature PEMFC and one-dimensional numerical analysis," Electrochimica Acta, vol. 52, no. 2, pp. 394-401, 2006.

[13] J. Kim, M. Kim, T. Kang, Y.-J. Sohn, T. Song, and K. H. Choi, "Degradation modeling and operational optimization for improving the lifetime of high-temperature PEM (proton exchange membrane) fuel cells," Energy, vol. 66, pp. 41-49, 2014.

[14] Y. Zhai, H. Zhang, G. Liu, J. Hu, and B. Yi, "Degradation study on MEA in $\mathrm{H}_{3} \mathrm{PO}_{4} / \mathrm{PBI}$ high-temperature PEMFC life test," Journal of the Electrochemical Society, vol. 154, no. 1, pp. B72B76, 2007.

[15] G. Liu, H. Zhang, J. Hu, Y. Zhai, D. Xu, and Z.-G. Shao, "Studies of performance degradation of a high temperature PEMFC based on $\mathrm{H}_{3} \mathrm{PO}_{4}$-doped PBI," Journal of Power Sources, vol. 162, no. 1, pp. 547-552, 2006.

[16] A. Orfanidi, M. K. Daletou, L. Sygellou, and S. G. Neophytides, "The role of phosphoric acid in the anodic electrocatalytic layer in high temperature PEM fuel cells," Journal of Applied Electrochemistry, vol. 43, no. 11, pp. 1101-1116, 2013.

[17] P. Boillat, J. Biesdorf, P. Oberholzer, A. Kaestner, and T. J. Schmidta, "Evaluation of neutron imaging for measuring phosphoric acid distribution in high temperature PEFCs," Journal of the Electrochemical Society, vol. 161, no. 3, pp. F192-F198, 2014.

[18] R. Zeis, "Materials and characterization techniques for hightemperature polymer electrolyte membrane fuel cells," Beilstein Journal of Nanotechnology, vol. 6, no. 1, pp. 68-83, 2015.

[19] S. Galbiati, A. Baricci, A. Casalegno, and R. Marchesi, "Experimental study of water transport in a polybenzimidazole-based high temperature PEMFC," International Journal of Hydrogen Energy, vol. 37, no. 3, pp. 2462-2469, 2012.
[20] S. Bose, T. Kuila, T. X. H. Nguyen, N. H. Kim, K.-T. Lau, and J. H. Lee, "Polymer membranes for high temperature proton exchange membrane fuel cell: recent advances and challenges," Progress in Polymer Science, vol. 36, no. 6, pp. 813-843, 2011.

[21] Y. Oono, A. Sounai, and M. Hori, "Influence of the phosphoric acid-doping level in a polybenzimidazole membrane on the cell performance of high-temperature proton exchange membrane fuel cells," Journal of Power Sources, vol. 189, no. 2, pp. 943-949, 2009.

[22] S. Lang, T. J. Kazdal, F. Kühl, and M. J. Hampe, "Experimental investigation and numerical simulation of the electrolyte loss in a HT-PEM fuel cell,' International Journal of Hydrogen Energy, vol. 40, no. 2, pp. 1163-1172, 2015.

[23] S. Subianto, "Recent advances in polybenzimidazole/phosphoric acid membranes for high-temperature fuel cells," Polymer International, vol. 63, no. 7, pp. 1134-1144, 2014.

[24] S. H. Eberhardt, F. Marone, M. Stampanoni, F. N. Büchi, and T. J. Schmidt, "Quantifying phosphoric acid in high-temperature polymer electrolyte fuel cell components by X-ray tomographic microscopy," Journal of Synchrotron Radiation, vol. 21, part 6, pp. 1319-1326, 2014.

[25] T. G. Towns, "Determination of aqueous phosphate by ascorbic acid reduction of phosphomolybdic acid," Analytical Chemistry, vol. 58, no. 1, pp. 223-229, 1986.

[26] M. I. Karayannis, D. N. Samios, and C. H. P. Gousetis, "A study of the molar absorptivity of ascorbic acid at different wavelengths and $\mathrm{pH}$ values," Analytica Chimica Acta, vol. 93, pp. 275-279, 1977.

[27] Y. S. Sin, A Flow Injection Analysis Method for the Determination of Low-Level Phosphate Base on the Formation the Ion Associate between Molybdophosphate and Rhodamnie B, Yonsei University, 2000.

[28] K. Hyun-Bin, A Study on the Analysis Methods for the Determination of Low Level Cenctration of Orthophospate, Department of Environmental Science, Yonsei University, Seoul, Republic of Korea, 2000.

[29] D. N. Fogg and N. T. Wilkinson, "The colorimetric determination of phosphorus," Journal, vol. 83, no. 988, pp. 406-414, 1958.

[30] T. Kuttner and L. Lichtenstein, "Micro colorimetric studies II. Estimation of phosphorus: molybdic acid-stannous chloride reagent," Journal of Biological Chemistry, vol. 86, no. 2, pp. 671676, 1930.

[31] L. Drummond and W. Maher, "Determination of phosphorus in aqueous solution via formation of the phosphoantimonylmolybdenum blue complex. Re-examination of optimum conditions for the analysis of phosphate," Analytica Chimica Acta, vol. 302, no. 1, pp. 69-74, 1995.

[32] G. F. Kirkbright, R. Narayanaswamy, and T. S. West, "Spectrofluorimetric determination of orthophosphate as rhodamine B molybdophosphate," Analytical Chemistry, vol. 43, no. 11, pp. 1434-1438, 1971.

[33] I. Debruyne, "Inorganic phosphate determination: colorimetric assay based on the formation of a rhodamine Bphosphomolybdate complex," Analytical Biochemistry, vol. 130, no. 2, pp. 454-460, 1983.

[34] A. G. Fogg, S. Soleymanloo, and D. T. Burns, “The spectrophotometric determination of inorganic phosphate in biological systems with crystal violet," Analytica Chimica Acta, vol. 88, no. 1, pp. 197-200, 1977. 
[35] S. Haykin and B. Widrow, Least-Mean-Square Adaptive Filters, John Wiley \& Sons, 2003.

[36] R. W. Ricci, M. A. Ditzler, and L. P. Nestor, "Discovering the Beer-Lambert law," Journal of Chemical Education, vol. 71, no. 11, pp. 983-985, 1994. 


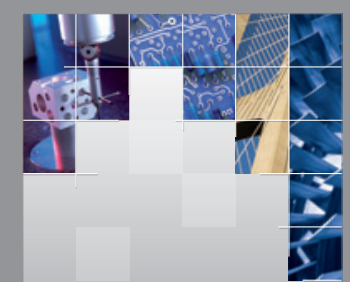

\section{Enfincering}
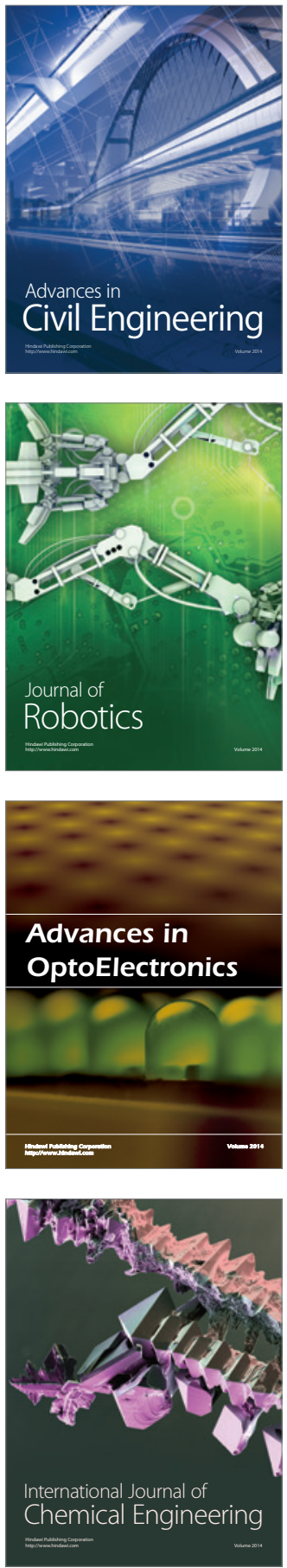

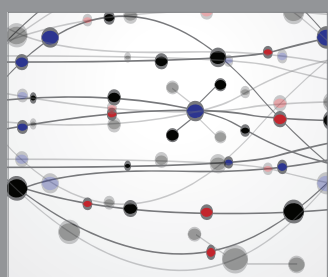

The Scientific World Journal

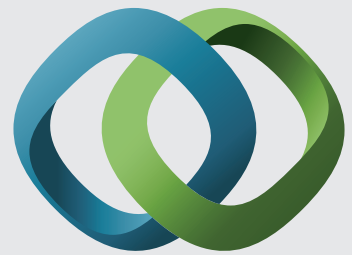

\section{Hindawi}

Submit your manuscripts at

http://www.hindawi.com
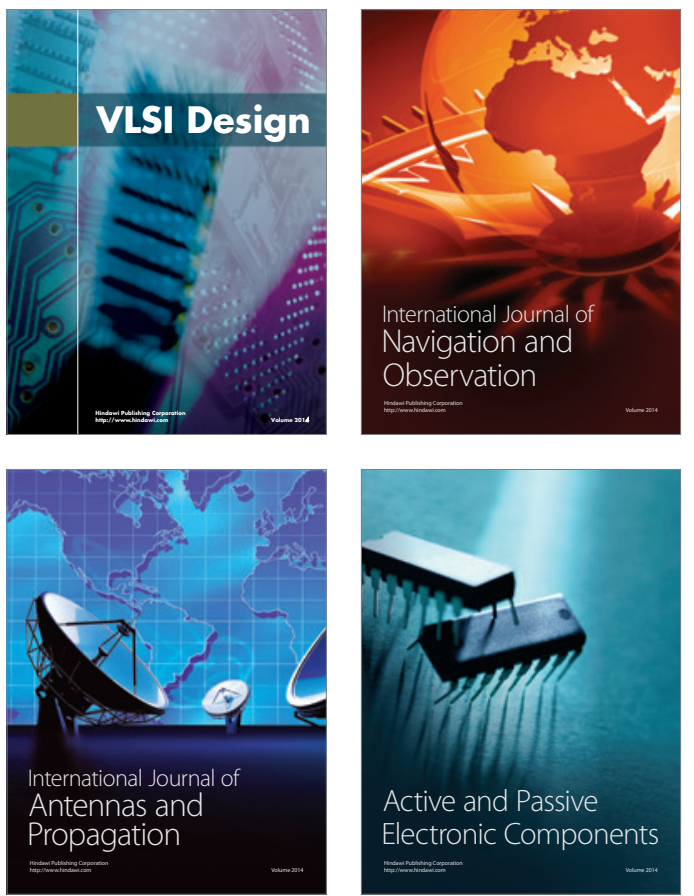
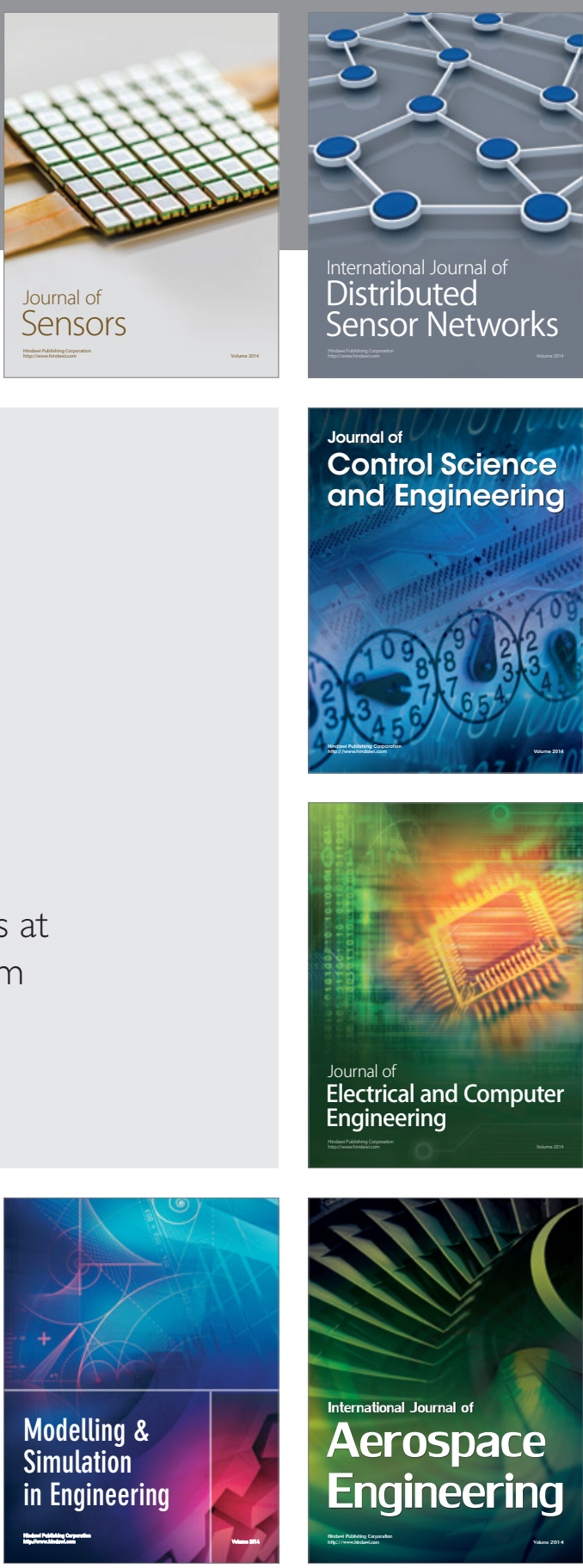

International Journal of

Distributed

Sensor Networks

Journal of

Control Science

and Engineering
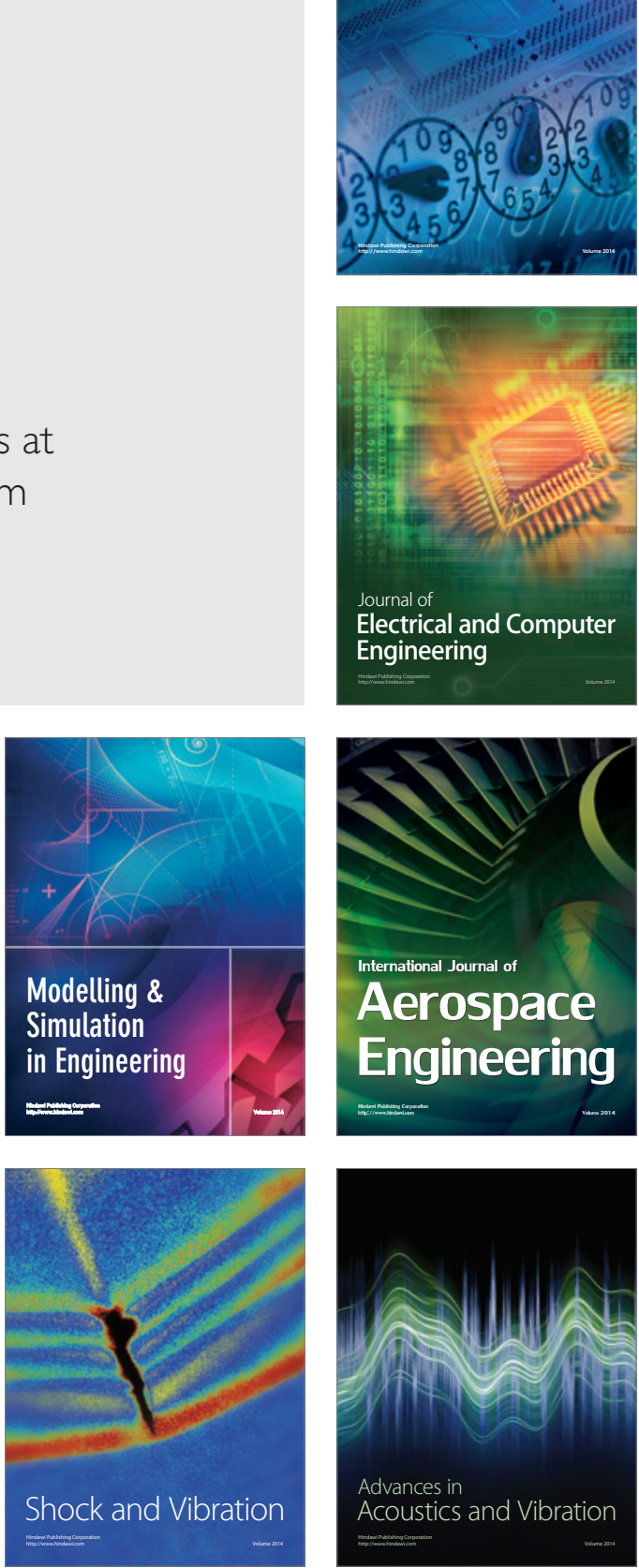